\title{
Anti-tumor activity and toxicokinetics analysis of MGAH22, an anti-HER2 monoclonal antibody with enhanced $F c \gamma$ receptor binding properties
}

Jeffrey L Nordstrom ${ }^{1 *}$, Sergey Gorlatov ${ }^{1}$, Wenjun Zhang ${ }^{1}$, Yinhua Yang ${ }^{1}$, Ling Huang ${ }^{1}$, Steve Burke ${ }^{1}$, Hua Li', Valentina Ciccarone ${ }^{1}$, Tengfei Zhang ${ }^{1}$, Jeffrey Stavenhagen ${ }^{1,2}$, Scott Koenig ${ }^{1}$, Stanford J Stewart ${ }^{1}$, Paul A Moore ${ }^{1}$, Syd Johnson ${ }^{1}$ and Ezio Bonvini ${ }^{1}$

\begin{abstract}
Introduction: Response to trastuzumab in metastatic breast cancer correlates with expression of the high binding variant (158V) of the activating Fcy receptor IIIA (CD16A). We engineered MGAH22, a chimeric anti-HER2 monoclonal antibody with specificity and affinity similar to trastuzumab, with an Fc domain engineered for increased binding to both alleles of human CD16A.

Methods: MGAH22 was compared to an identical anti-HER2 mAb except for a wild type Fc domain. Antibodydependent cell cytotoxicity (ADCC) assays were performed with HER2-expressing cancer cells as targets and human PBMC or purified NK cells as effectors. Xenograft studies were conducted in mice with wild type murine FcyRs; in mice lacking murine CD16; or in mice lacking murine CD16 but transgenic for human CD16A-158F, the lowbinding variant. The latter model reproduces the differential binding between wild type and the Fc-optimized mAb for human CD16A. The JIMT-1 human breast tumor line, derived from a patient that progressed on trastuzumab therapy, was used in these studies. Single and repeat dose toxicology studies with MGAH22 administered intravenously at high dose were conducted in cynomolgus monkeys.

Results: The optimized FC domain confers enhanced ADCC against all HER2-positive tumor cells tested, including cells resistant to trastuzumab's anti-proliferative activity or expressing low HER2 levels. The greatest improvement occurs with effector cells isolated from donors homozygous or heterozygous for CD16A-158F, the low-binding allele. MGAH22 demonstrates increased activity against HER2-expressing tumors in mice transgenic for human CD16A-158F. In single and repeat-dose toxicology studies in cynomolgus monkeys, a species with a HER2 expression pattern comparable to that in humans and Fcy receptors that exhibit enhanced binding to the optimized Fc domain, MGAH22 was well tolerated at all doses tested $(15-150 \mathrm{mg} / \mathrm{kg})$ and exhibited pharmacokinetic parameters similar to that of other anti-HER2 antibodies. Induction of cytokine release by MGAH22 in vivo or in vitro was similar to that induced by the corresponding wild type mAb or trastuzumab.
\end{abstract}

Conclusions: The data support the clinical development of MGAH22, which may have utility in patients with low HER2 expressing tumors or carrying the CD16A low-binding allele.

\footnotetext{
* Correspondence: nordstromj@macrogenics.com

'MacroGenics, Inc., 9640 Medical Center Drive, Rockville, MD 20850, USA

Full list of author information is available at the end of the article
} 


\section{Introduction}

HER2, an overexpressed cell-surface oncoprotein that contributes to breast, gastric, and other cancers [1], is a validated therapeutic target, as evidenced by clinical success of the monoclonal antibody (mAb) trastuzumab [2-5]. Trastuzumab acts against HER2-positive tumors by multiple mechanisms, including receptor internalization, receptor 'shedding', direct anti-proliferative activity, antibody-dependent cell-mediated cytotoxicity (ADCC), and presentation of antigenic determinants of opsonized cells to antigen-presenting cells [6]. The latter mechanisms depend upon the interaction of the Fc domain of trastuzumab with Fc-gamma receptors (Fc $\gamma$ Rs) expressed by immune effector populations, such as natural killer (NK) cells or mononuclear phagocytes [7-10]. Polymorphic variants of certain activating Fc $\gamma$ Rs predict response duration to trastuzumab: patients homozygous for CD16A (Fc $\gamma$ RIIIA) 158V allele or CD32A (Fc $\gamma$ RIIA) $131 \mathrm{H}$ allele or both have longer progression-free survival than patients carrying the respective $158 \mathrm{~F}$ or $131 \mathrm{R}$ alleles [11], which bind the Fc domain of immunoglobulin G 1 (IgG1), the main class of therapeutic mAbs, such as trastuzumab, with lower affinity than their allelic counterparts.

Fc $\gamma \mathrm{R}$ polymorphism influences the clinical response to several IgG1 mAbs other than trastuzumab. While the relationship between CD16A polymorphism and benefit is controversial for cetuximab [12-15], CD16-158V and CD32A-131H homozygosity appear to be associated with beneficial responses for rituximab and infliximab [16-18]. Furthermore, for an agonistic anti-death receptor antibody with intrinsic anti-tumor activity that is potentiated by Fc $\gamma \mathrm{R}$ interactions, effector cells expressing the higher-binding CD16A and CD32A variants supported substantially greater proapoptoptic activity [19]. CD16A-158V homozygotes represent $10 \%$ to $20 \%$ of the population worldwide, whereas CD32A-131H homozygotes represent approximately $25 \%$ of Caucasians or Africans and $50 \%$ to $60 \%$ of Asians [20,21]. Thus, Fc $\gamma \mathrm{R}$ genotypes most frequently associated with greater beneficial responses occur in a minority of the population. This provides a strong rationale for engineering the Fc domain of trastuzumab to better interact with low-binding alleles of activating Fc $\gamma$ Rs to expand, without regard to Fc $\gamma R$ genotype, the benefit of treatment to patients.

MGAH22 is an Fc-engineered mAb designed for increased binding to both alleles of CD16A and preservation of the direct anti-proliferative activity of trastuzumab. Since trastuzumab activity is enhanced in mice genetically deficient for the inhibitory Fc $\gamma R$, CD32B (Fc $\gamma$ RIIB) [7], a negative regulator of activation of monocytes, macrophages, and dendritic cells [22], the Fc domain of MGAH22 was also engineered for reduced CD32B binding. The optimized Fc domain confers enhanced ADCC activity against HER2-positive tumors, including low HER2 expressors, independently of the Fc $\gamma R$ variant for the effector cells. MGAH22 is active in vitro and in vivo against a HER2-positive tumor line derived from a patient whose tumor progressed while on trastuzumab. Because changes in effector cell interactions could have safety implications, high-dose MGAH22 toxicology studies were conducted in cynomolgus monkeys, a relevant species, with no significant antibody-related safety findings.

The enhanced properties of MGAH22 suggest potential clinical utility in extending the benefit of anti-HER2 immunotherapy to patients independently of their CD16A allelic expression and to patients who, because of low HER2 expression levels, do not qualify for trastuzumab treatment as well as to patients whose tumors progress while on trastuzumab.

\section{Materials and methods}

\section{Human tumor cell lines}

Breast (MCF-7, ZR-75-1, and SKBR-3), gastric (N87), colon (HT-29), and bladder (SW780) lines were obtained from the American Type Culture Collection (Manassas, VA, USA), and JIMT-1 (breast) was obtained from DSMZ (Braunschweig, Germany). All cell lines were cultured in accordance with recommended specifications for fewer than 30 passages. The number of HER2-binding sites per cell and immunohistochemistry category ( 0 to $3+$ ) were determined by flow cytometry (QuantiBRITE ${ }^{\mathrm{TM}}$ PE; BD Biosciences, San Jose, CA, USA) and HercepTest ${ }^{\mathrm{TM}}$ (Dako, Carpinteria, CA, USA): MCF-7 (14,000; 1+), HT-29 (25,000; 1+), SW780 (37,000; 1+), ZR-75-1 (52,000; 2+), JIMT-1 (79,000; 2+); N87 (270,000; 2+), and SKBR-3 (540,000; 3+).

\section{Antibodies}

ch4D 5 was generated by fusing synthetic sequences encoding light- and heavy-chain variable domains of 4D5, the murine precursor of trastuzumab [23], to human $\kappa$ and IgG1 constant domains, respectively. RES120 was generated from ch4D5 by light-chain mutagenesis (N65S) to eliminate a consensus $\mathrm{N}$-glycosylation site. MGAH22 was generated from RES120 by exchanging its Fc domain for MGFc0264 (L235V, F243L, R292P, Y300L, and P396L) [24,25]. ch4D5-N297Q, which contains an inactivated Fc domain, was derived from ch4D5 by mutating the heavy-chain $\mathrm{N}$-glycosylation site.

\section{Fc-gamma receptor binding}

Binding of soluble forms of Fc $\gamma$ Rs (either monomeric extracellular domains or dimeric inactivated Fc-G2 
fusions) to Fc domains was analyzed by surface plasmon resonance after capture of antibodies to immobilized HER2 [25].

\section{In vitro anti-proliferation activity}

Tumor cells $\left(2 \times 10^{4}\right.$ per well $)$ were incubated for 6 days with antibodies at $37^{\circ} \mathrm{C}$, and proliferation/viability was detected by using the CellTiterGlo Luminescent Cell Viability Assay Kit (Promega Corporation, Madison, WI, USA).

\section{Antibody-dependent cell-mediated cytotoxicity}

Peripheral blood mononuclear cells (PBMCs) were isolated from healthy human donor blood (Ficoll-Paque ${ }^{\mathrm{TM}}$ Plus; GE Healthcare, Piscataway, NJ, USA). NK cells were purified (Untouched Human NK cell isolation kit; Dynal, Invitrogen Corporation, Carlsbad, CA, USA). Target cells $\left(2 \times 10^{4}\right.$ per well $)$ were incubated with antibodies for 30 minutes at $37^{\circ} \mathrm{C}$ in RPMI-1640 (without phenol red), $10 \%$ fetal bovine serum, and $2 \mathrm{mM}$ Gluta$\mathrm{Max}^{\mathrm{TM}}$ (Invitrogen Corporation) before adding effector cells at an effector/target ratio of 30:1 (PBMCs) or 3:1 (purified NK cells). Lactate dehydrogenase release (Promega Corporation) was measured after overnight incubation. Cytotoxicity (expressed as a percentage) $=$ (experimental cell lysis-antibody-independent cell cytoly$\mathrm{sis}) /$ (maximum target lysis-spontaneous target lysis) $\times$ 100. Fc $\gamma \mathrm{R}$ genotypes were determined by sequencing polymerase chain reaction-amplified DNA.

\section{Treatment of xenograft tumors in mice}

All mouse experiments were performed at our facility under protocols approved by the MacroGenics Institutional Animal Care and Use Committee. RAG2 ${ }^{-/-}$Balb/ c mice (WT Fc $\gamma \mathrm{R}$ mice) were obtained from Taconic (Rockville, MD, USA). mCD16 $6^{-/-} \mathrm{RAG}^{-/-} \mathrm{Balb} / \mathrm{c}$ mice (mCD16 knockouts) and mCD16 ${ }^{-/-} \mathrm{hCD} 16 \mathrm{~A}^{+} \mathrm{RAG}^{-1-}$ mice (mCD16 knockouts transgenic for hCD16A-158F) were bred at MacroGenics. JIMT-1 cells $\left(5 \times 10^{6}\right.$ per mouse) in phosphate-buffered saline plus Matrigel were implanted subcutaneously and antibodies administered intraperitoneally weekly beginning at the time of tumor implantation or after tumors of approximately $200 \mathrm{~mm}^{3}$ had been allowed to form. Tumor sizes were monitored three times weekly by orthogonal measurements with electronic calipers. Statistical differences in tumor sizes were assessed by two-way analyses of variance and Bonferroni post-test analyses (GraphPad Prism 5.02; GraphPad Software, Inc., La Jolla, CA, USA).

\section{Toxicology/toxicokinetics in non-human primates}

Cynomolgus monkey experiments were conducted at Charles River Laboratories (Sparks, NV, USA) in accordance with Testing Facility Standard Operating Procedure, which adheres to the regulations outlined in the US Department of Agriculture Animal Welfare Act [26] and the conditions specified in the Guide for the Care and Use of Laboratory Animals [27]. The study protocols were approved by the Testing Facility Institutional Animal Care and Use Committee. A single-dose study was conducted with 12 cynomolgus monkeys randomly assigned to two groups (three per sex per group) receiving MGAH22 or RES120 at $50 \mathrm{mg} / \mathrm{kg}$ by $60-\mathrm{min}-$ ute intravenous infusion. All animals were euthanized at day 62 for necropsies. A repeat-dose study was conducted with 40 monkeys randomly assigned to four groups (five per sex per group) receiving vehicle or MGAH22 weekly for 6 weeks at 15, 50, or $150 \mathrm{mg} / \mathrm{kg}$ by 60 -minute intravenous infusion. Twenty-four (three per sex per group) were euthanized on day 40, 4 days after the last dose, and 16 (two per sex per group) were followed for a recovery period of 56 days and euthanized on day 93 for necropsies.

\section{Measurement of serum MGAH22 concentration by enzyme-linked immunosorbent assay}

Goat anti-MGAH22-Fv antibody was used to capture MGAH22 (or RES120) from cynomolgus serum and this was followed by detection with biotinylated goat antiMGAH22-Fv antibody plus streptavidin-alkaline phosphatase conjugate and 4-methylumbelliferyl phosphate as substrate. Product was measured by using a fluorescent microplate reader against a standard curve (fourparameter non-linear curve fitting). The minimum quantifiable concentration was $4.25 \mathrm{ng} / \mathrm{mL}$.

\section{Measurement of cytokine release}

$\mathrm{BD}^{\mathrm{TM}}$ human Th1/Th2 cytometric bead array (CBA) and Human IL-5 Flex Set CBA were used to measure levels of IL-2, IL-4, IL-5, IL-6, IL-10, tumor necrosis factor-alpha (TNF- $\alpha$ ), and interferon-gamma (IFN- $\gamma$ ) in serum collected at different times after intravenous administration of antibodies to cynomolgus monkeys. Statistical differences in relative changes from baseline were assessed by non-parametric van Elteren tests (an extension to the Wilcoxon rank-sum test) and Bonferroni adjustments for multiple comparisons (SAS 9.2; SAS Institute Inc., Cary, NC, USA). Cytokine levels were also measured in cell culture supernatants after incubation of human PBMCs with antibodies on plates left uncoated or coated with $1 \mu \mathrm{g} / \mathrm{mL}$ of HER2 antigen-recombinant human ErbB2/HER2 Fc chimera (R\&D Systems, Inc., Minneapolis, MN, USA), enzymatically deglycosylated-for 16 to 20 hours at $37^{\circ} \mathrm{C}$. Statistical differences in cytokine levels induced by the different antibodies were assessed by a Wilcoxon signed rank test (SAS 9.2). 


\section{Results}

MGAH22 preserves HER2-binding and anti-proliferative properties of trastuzumab

MGAH22 is a human/mouse chimeric IgG1 anti-HER2 antibody based on mouse clone 4D5, the precursor of trastuzumab [23] with an engineered Fc domain (MGFc0264) similar to the previously described Fc variant 18 [25], except that the V305I mutation was replaced by $\mathrm{L} 235 \mathrm{~V}$ to reduce CD32B binding. RES120, a molecule identical to MGAH22 except for a wildtype (WT) human IgG1 Fc domain, was used for comparison and as a trastuzumab surrogate. MGAH22 preserves the HER2-binding properties of RES120 and authentic trastuzumab (Figure 1a). Proliferation of SKBR-3 cells is sensitive to trastuzumab [23], whereas proliferation of JIMT-1 cells, a line with HER2 gene amplification but moderate expression and derived from a breast cancer patient whose metastatic tumor had progressed while on trastuzumab, is insensitive to trastuzumab [28]. MGAH22, RES120, and trastuzumab exhibit anti-proliferative activity indistinguishable from each other against SKBR-3 cells, but none shows activity against JIMT-1 cells (Figure $1 \mathrm{~b}$ ). Thus, the Fc domain modifications of MGAH22 do not influence

\section{A. HER2 Binding}

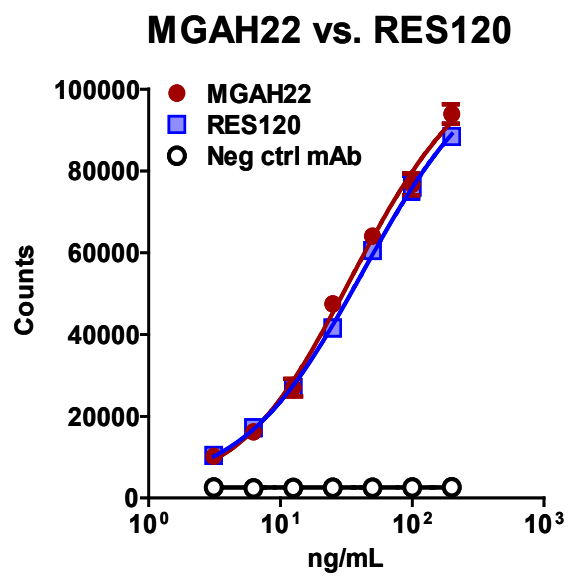

\section{MGAH22 vs. trastuzumab}

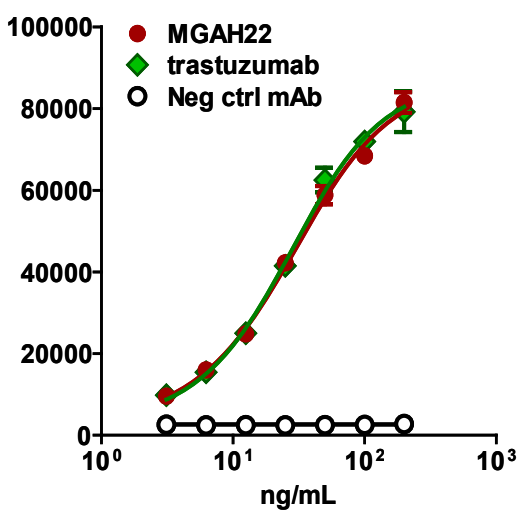

\section{B. Proliferation}

JIMT-1

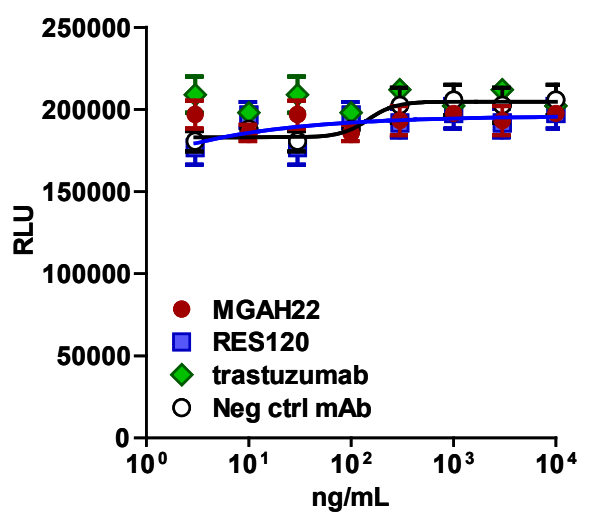

SKBR-3

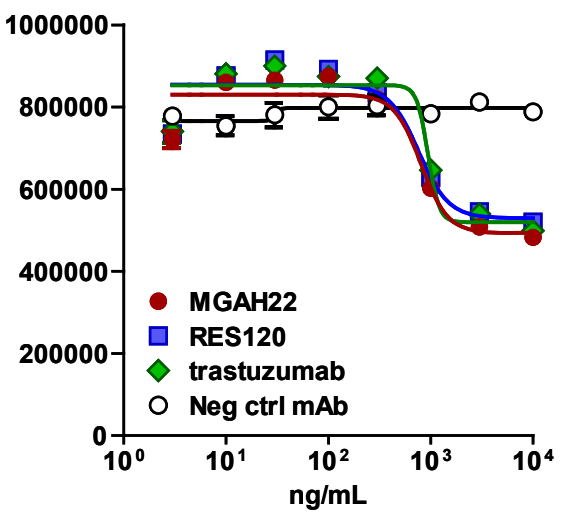

Figure 1 HER2-binding and anti-proliferative activity. (a) HER2-binding activity of MGAH22 was compared with RES120 or trastuzumab by antigen-capture enzyme-linked immunosorbent assay. EC 50 (and 95\% confidence interval) values were 39.33 (29.45 to 52.52) ng/mL for MGAH22 and 45.75 (33.37 to 62.67) ng/mL for RES120 (left panel) and 28.76 (24.96 to 33.15) for MGAH22 and 27.28 (23.6 to 31.53) ng/mL for trastuzumab (right panel). (b) Proliferation of JIMT-1 and SKBR-3 cells in the presence of MGAH22, RES120, or trastuzumab. Data are presented as mean \pm standard error of the mean. $\mathrm{EC}_{50}$, effective concentration for 50\% binding; MGAH22, chimeric anti-HER2 monoclonal antibody with an optimized Fc domain; Neg ctrl mAb, negative control monoclonal antibody; RES120, chimeric anti-HER2 monoclonal antibody with wild-type human immunoglobulin G 1 Fc domain; RLU, relative light units. 
the antigen recognition and anti-proliferative activity in the absence of effector cells.

\section{Binding of the optimized Fc domain to Fc-gamma receptors}

Binding profiles of soluble Fc $\gamma$ Rs to mAbs with WT or optimized Fc domains were determined (Figure 2). Compared with the WT Fc domain, the optimized MGFc0264 domain demonstrates increased affinity for both alleles of human CD16A (equilibrium dissociation constant $\left(K_{D}\right)$ for $158 \mathrm{~V}$ : from $415 \mathrm{nM}$ to $89 \mathrm{nM}$; $K_{D}$ for 158F: from $1,059 \mathrm{nM}$ to $161 \mathrm{nM}$ ) but decreased binding to human CD32B, inhibitory Fc $\gamma \mathrm{R}\left(\mathrm{K}_{\mathrm{D}}\right.$ : from
$52 \mathrm{nM}$ to $437 \mathrm{nM})$. It similarly imparts decreased binding to the 131R allele of human activating Fc $\gamma R$, CD32A ( $\mathrm{K}_{\mathrm{D}}$ : from $36 \mathrm{nM}$ to $218 \mathrm{nM}$ ), but binding to the $131 \mathrm{H}$ allele is not substantially modified $\left(K_{\mathrm{D}}\right.$ : from $39 \mathrm{nM}$ to $34 \mathrm{nM}$ ). Owing to the substantially low affinity of human CD32A/B, $K_{D}$ values were obtained for the bivalent Fc fusion versions of these receptors (whose Fc domain was inactivated via N297Q or D265A mutation to eliminate homologous interactions); this strategy provides adequate sensitivity, due to avidity effects, to determine binding differences. The optimized Fc domain shows increased binding to human C1q. Binding to human CD64 (the high-affinity

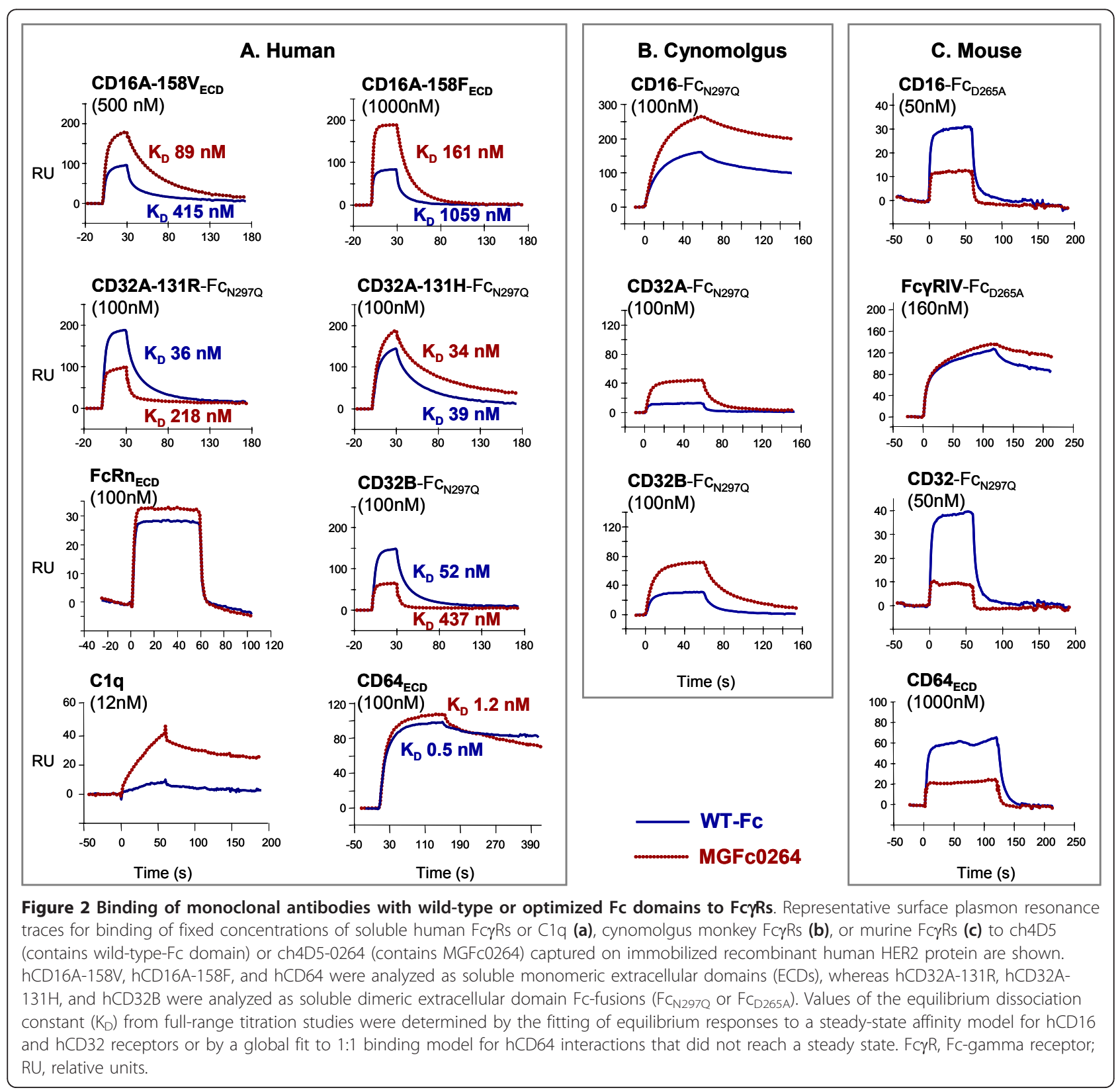


activating $F c \gamma R$ ) and FcRn (the neonatal Fc $\gamma R$ ) is not substantially modified.

Compared with either allele of human CD16A, the WT human Fc domain exhibits increased binding to cynomolgus monkey CD16A, which has an invariant isoleucine at position 158 [29]. The optimized Fc domain imparts further increases in binding to monkey CD16A and CD32A (Figure 2b). In contrast to the decreased binding observed with human CD32B, MGFc0264 shows increased binding to monkey CD32B and this is most likely attributable to differences at position 131 ( $\mathrm{R}$ in human and $\mathrm{H}$ in cynomolgus).

Murine CD16 is a low-affinity activating Fc $\gamma \mathrm{R}$ that is approximately $60 \%$ homologous to human CD32A but that, similarly to human CD16A, is distributed on murine NK cells and mononuclear phagocytes [22]. Binding of the optimized Fc domain of MGAH22 to murine CD16 is reduced (Figure 2c) and this contrasts to its increased binding to human or cynomolgus monkey CD16A. As with human CD32B, the optimized Fc domain imparts reduced binding to CD32, the mouse inhibitory Fc $\gamma \mathrm{R}$ (mice lack a CD32A ortholog), and reduced binding to murine $\mathrm{CD} 64$ and this contrasts with the minimal change observed with human CD64. Both WT and optimized human Fc domains bind similarly to mouse Fc $\gamma$ RIV, although MGAH22 shows slightly improved binding (slower off-rate). Fc $\gamma$ RIV is another low-affinity activating Fc $\gamma \mathrm{R}$ most closely related to human CD16A in sequence, but to human CD32A in distribution, because expression is restricted to murine myeloid cells and is absent on NK cells; furthermore, data suggest a potential functional relationship to human FceRI $[22,30,31]$.

MGAH22 enhances the antibody-dependent cell-mediated cytotoxicity activity of effector cells expressing the CD16A-158F variant

For ADCC assays, effector cells were isolated from human donors of different CD16A genotypes. Compared with RES120, MGAH22 showed increased maximum lysis and lower effective concentration for $50 \%$ lysis $\left(\mathrm{EC}_{50}\right.$ ) with $\mathrm{CD} 16 \mathrm{~A} \mathrm{~F} / \mathrm{F}$ or V/F effector cells (purified NK cells) against JIMT-1 breast cancer cells (Figure 3ae). With CD16A V/V effector cells, MGAH22 exhibited lower $\mathrm{EC}_{50}$ but was unaccompanied by enhanced maximum lysis. In these experiments, ch4D5-N297Q was inactive, confirming the requirement for a functional Fc domain.

MGAH22 mediates efficient antibody-dependent cellmediated cytotoxicity against tumor cells expressing low HER2 levels

MGAH22 demonstrated ADCC activity with $\mathrm{EC}_{50}$ values lower than those of RES120 against breast and non- breast cancer cell lines encompassing a wide range of surface HER2 expression with effector cells (PBMCs) from CD16A F/F or V/F donors (Figure 3f-m). No activity occurred when a HER2-negative breast cancer cell line (MDA-MB-468) [32] was tested (data not shown). The increase in maximum lysis with MGAH22 was inversely proportional to HER2 levels, and the greatest enhancement occurred with cells expressing lower HER2 densities. At very high HER2 levels, such as with SKBR-3 target cells, no increase in maximum lysis was observed with MGAH22; however, a substantial decrease in $\mathrm{EC}_{50}$ was still observed.

\section{Increased anti-tumor activity of MGAH22 in mice transgenic for human CD16A-158F}

While mice bearing human tumor xenografts are commonly used to demonstrate anti-tumor activity of human IgG1 mAbs, mouse Fc $\gamma$ Rs are distributed and bind human IgG1 differently than their human counterparts (compare Figures 2a and 2c). This hampers the utilization of mouse xenograft models to assess the functional properties of mAbs optimized for human Fc $\gamma R$ interactions. To ascertain the role of Fc $\gamma$ Rs in MGAH22 anti-tumor activity, xenograft studies employed three mouse strains: Fc $\gamma$ R-WT mice (WT murine $\mathrm{Fc} \gamma \mathrm{R}$ repertoire), $\mathrm{mCD} 16^{-/-}$mice (lacking murine $\mathrm{CD} 16$ ), and $\mathrm{mCD}_{16}{ }^{-1-} \mathrm{hCD} 16 \mathrm{~A}^{+}$mice (lacking $\mathrm{mCD} 16$ but transgenic for human CD16A-158F, the low-binding allele). In this transgenic mouse strain, human CD16A$158 \mathrm{~F}$ is expressed by NK cells and mononuclear phagocytes [25], similarly to its cell type-specific expression in humans [33]. Although mFc $\gamma$ RIV expression is preserved, this transgenic mouse model effectively eliminates the confounding factor caused by differential binding to mCD16.

JIMT-1 cells, which are insensitive to direct inhibition (Figure 1b), were selected for xenograft studies to eliminate confounding components pertaining to the antiproliferative activity of anti-HER2 mAbs. This was confirmed by treating Fc $\gamma$ R-WT mice bearing JIMT-1 xenografts with the Fc domain inactive ch4D5-N297Q mAb, which showed no anti-tumor activity (Figure 4a), indicating that only Fc-dependent mechanisms mediate activity against these xenografts. When MGAH22 or RES120 was administered to the same xenograft-bearing Fc $\gamma$ R-WT mice, tumor growth was modestly inhibited, and the two antibodies were equally active. Administration of either $\mathrm{mAb}$ to $\mathrm{mCD} 16^{-/-}$tumor-bearing mice resulted in no anti-tumor activity (Figure $4 \mathrm{~b}$ ), and this suggests that mFc $\gamma$ RIV, in spite of its ability to bind to WT and optimized Fc domains, plays no role in this tumor model, possibly because of its lack of expression on NK cells and its restricted expression to myeloid cells. 


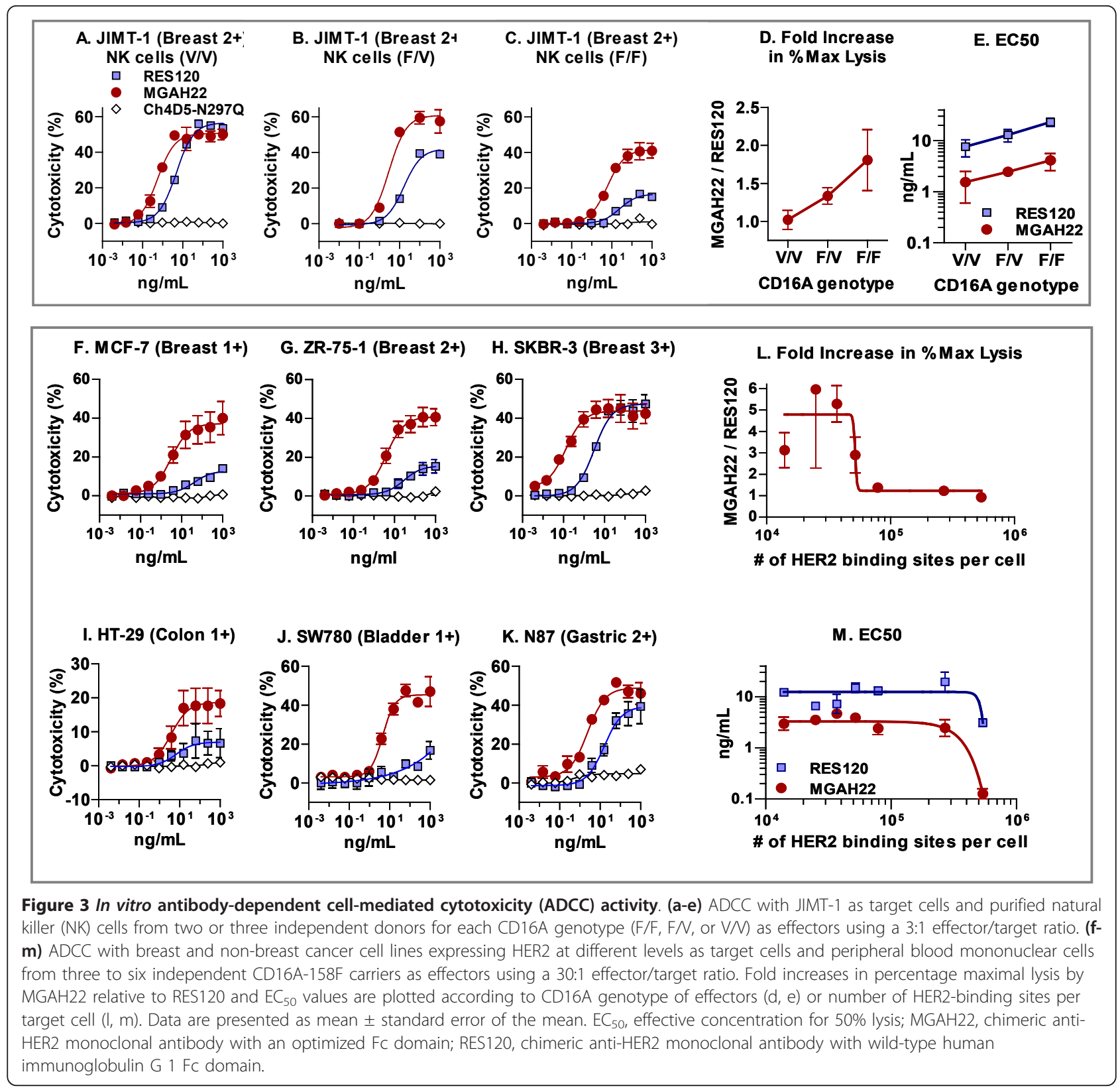

When administered to JIMT-1 xenograft-bearing $\mathrm{mCD}_{16}{ }^{-1-} \mathrm{hCD}_{16 \mathrm{~A}^{+}}$mice, MGAH22 exhibited enhanced anti-tumor activity compared with RES120 (Figure 4c), an activity attributable to the improved interaction between its optimized Fc domain and the human CD16A-158F (low-binding allele) receptor. In mCD16 $6^{-1-}$ $\mathrm{hCD} 16 \mathrm{~A}^{+}$mice with established JIMT-1 tumors, MGAH22 exhibited significant anti-tumor activity at weekly doses of 1 or $10 \mathrm{mg} / \mathrm{kg}$ (Figure 4e), whereas RES120 exhibited only marginal anti-tumor activity at $10 \mathrm{mg} / \mathrm{kg}$ and no activity at $1 \mathrm{mg} / \mathrm{kg}$ (Figure $4 \mathrm{~d}$ ). These data support the hypothesis that MGAH22 is more active than an anti-HER2 mAb with a WT Fc domain, such as trastuzumab.

\section{Pharmacokinetics in cynomolgus monkeys}

Pharmacokinetics of MGAH22 and RES120 were compared after single or repeated administrations in cynomolgus monkeys. Serum concentration-versus-time curves after a single dose of $50 \mathrm{mg} / \mathrm{kg}$ were biphasic, and pharmacokinetic parameters, calculated using a two-compartment elimination/distribution model, were similar for the two antibodies in males and females, except that the terminal elimination half-life of 


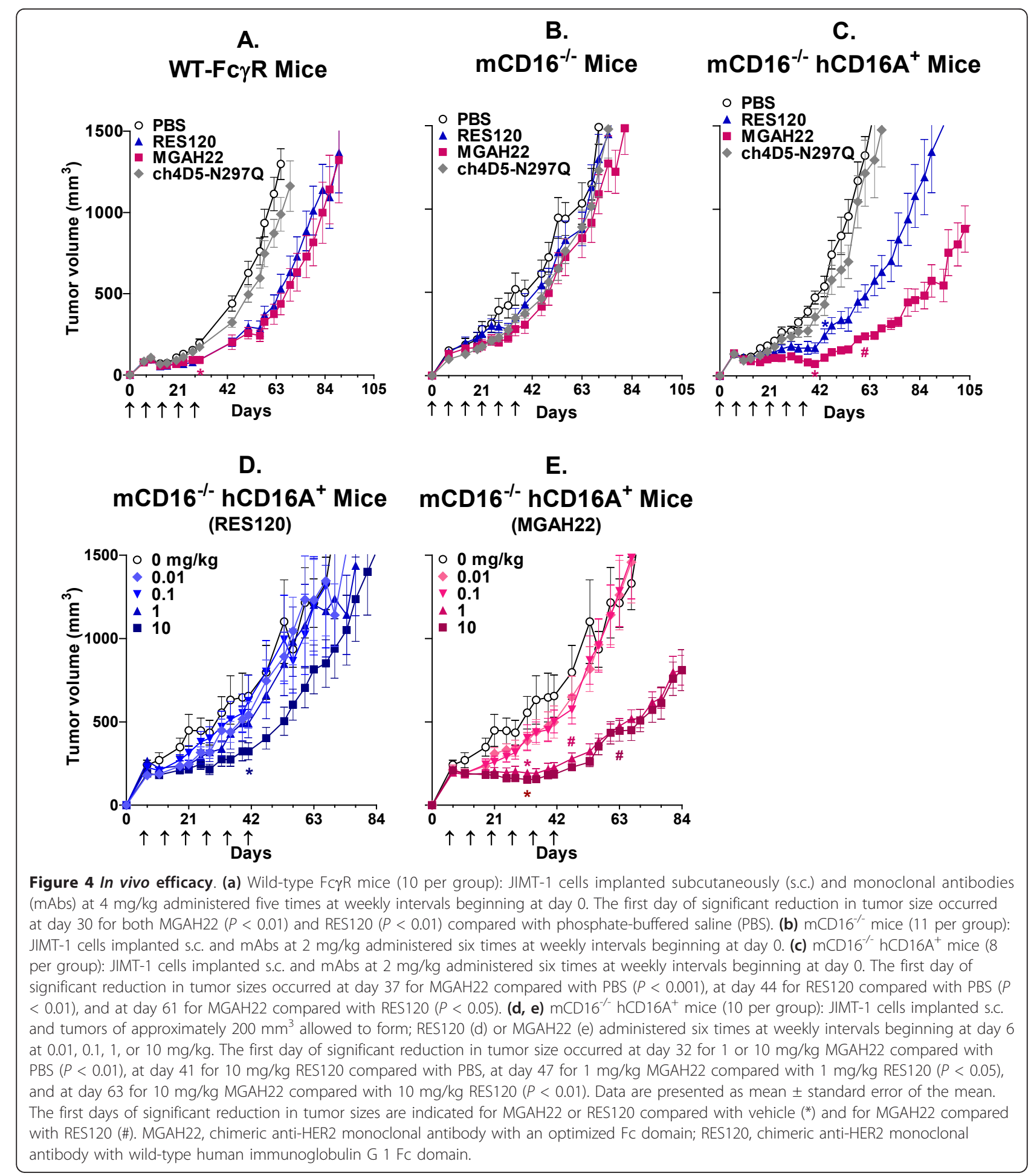

MGAH22 was approximately 20\% shorter than that of RES120 (9.3 to 9.7 versus 11.7 to 12 days) (Figure 5 and Table 1). Two of six animals that received MGAH22 exhibited a rapid decline in serum concentration at days 22 to 29 and tested positive for anti-drug antibodies (ADAs), whereas none of the six animals that received
RES120 were ADA-positive. In the repeat-dose study, MGAH22 was administered weekly for 6 weeks at doses of 15,50 , or $150 \mathrm{mg} / \mathrm{kg}$, and animals in the recovery groups were followed for 56 days after the last dose. Values of $\mathrm{C}_{\max }$ (maximal serum concentration) and $\mathrm{AUC}_{0-\infty}$ (area under the curve from zero to infinity) 


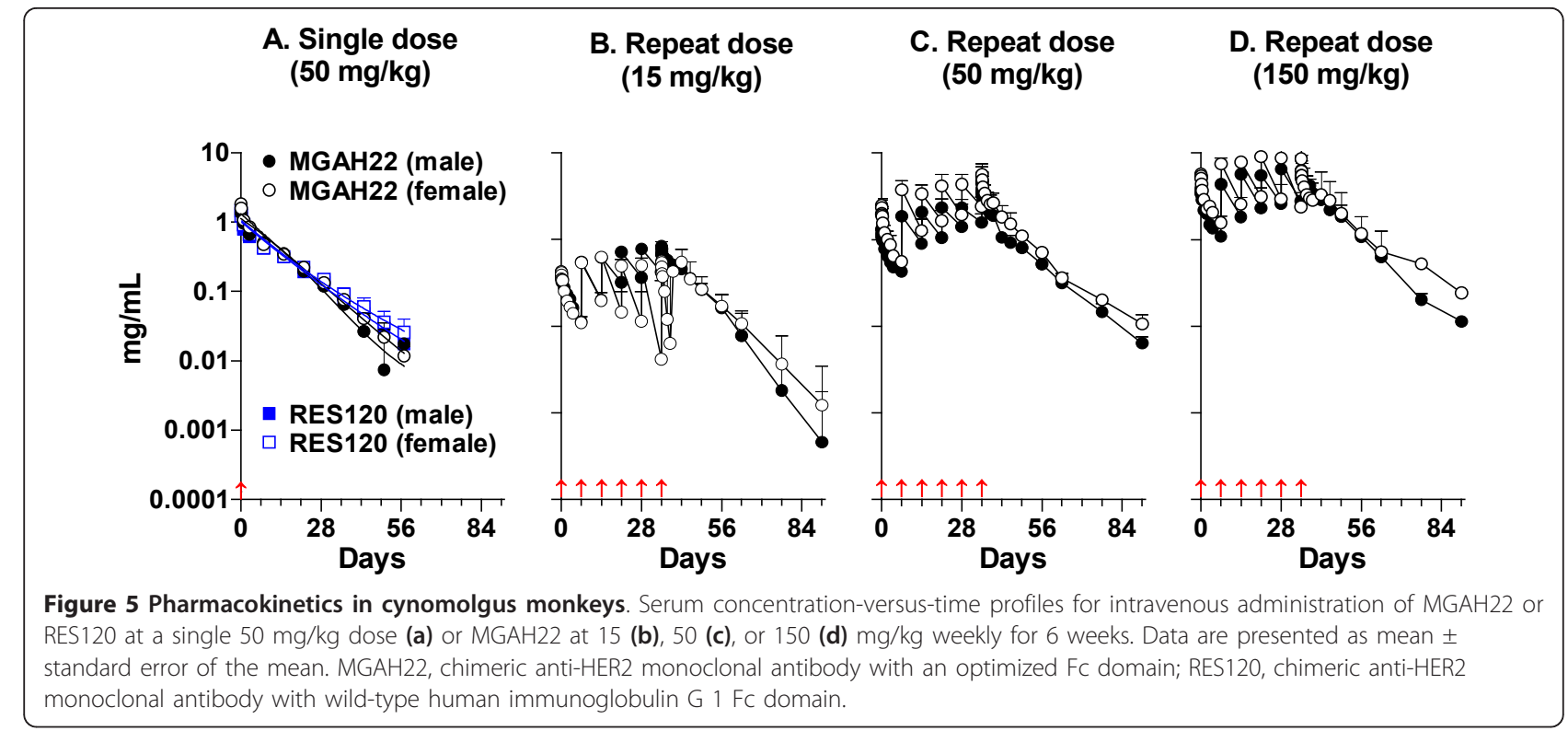

following the first dose appeared to increase linearly but were not dose-proportional after the sixth dose. Clearance was more rapid after the first dose than the sixth dose, and this likely reflects saturation of binding to target receptors. Terminal serum half-life was 7.3 to 8.9 days. One of the four animals in the low-dose recovery group exhibited a rapid decline in serum MGAH22 at the last few time points and tested positive for ADA at 56 days after the last dose, whereas ADA was not observed in any of the eight animals in the two higherdose recovery groups; thus, incidence of ADA against the Fc-engineered molecule was not common in monkeys receiving multiple doses. Overall, the pharmacokinetic parameters for MGAH22 in cynomolgus monkeys are consistent with those of other anti-HER2 mAbs $[34,35]$.

\section{Toxicology of MGAH22 in cynomolgus monkeys}

MGAH22 recognizes cynomolgus HER2, and cross-reactivity studies with MGAH22 and trastuzumab revealed similar staining patterns against human and cynomolgus tissue panels (data not shown). Cynomolgus monkeys

Table 1 Pharmacokinetic parameters for MGAH22 and RES120 in cynomolgus monkeys

\begin{tabular}{|c|c|c|c|c|c|c|c|c|}
\hline Study & Monoclonal antibody & Dose, $\mathrm{mg} / \mathrm{kg}$ & Sex & $C_{\text {max }}, \mathrm{mg} / \mathrm{mL}$ & $\mathrm{AUC}_{0-\#,}, \mathrm{mg}-\mathrm{hour} / \mathrm{mL}$ & $T_{1 / 2 b}$, days & Clearance, $\mathrm{mL} /$ hour & $\mathrm{V}_{\mathrm{ss}}, \mathrm{mL}$ \\
\hline \multirow[t]{4}{*}{ Single-dose } & RES120 & 50 & Male & $1.40 \pm 0.32$ & $285.7 \pm 4.2$ & $11.7 \pm 2.4$ & $0.44 \pm 0.01$ & $170 \pm 36$ \\
\hline & & & Female & $1.43 \pm 0.05$ & $311.8 \pm 54.6$ & $12.0 \pm 2.3$ & $0.41 \pm 0.07$ & $158 \pm 15$ \\
\hline & MGAH22 & 50 & Male & $1.62 \pm 0.10$ & $294.1 \pm 53.2$ & $9.3 \pm 1.8$ & $0.43 \pm 0.07$ & $132 \pm 2$ \\
\hline & & & Female & $1.70 \pm 0.14$ & $314.2 \pm 31.3$ & $9.7 \pm 1.1$ & $0.40 \pm 0.04$ & $127 \pm 8$ \\
\hline \multirow[t]{12}{*}{ Repeat-dose } & MGAH22 (first dose) & 15 & Male & $0.43 \pm 0.06$ & $57.0 \pm 11.2$ & $5.6 \pm 2.0$ & $0.82 \pm 0.18$ & $148 \pm 35$ \\
\hline & & & Female & $0.43 \pm 0.40$ & $42.8 \pm 9.7$ & $5.1 \pm 1.2$ & $1.09 \pm 0.24$ & $144 \pm 27$ \\
\hline & & 50 & Male & $1.37 \pm 0.23$ & $205.7 \pm 127.0$ & $6.9 \pm 5.0$ & $0.82 \pm 0.28$ & $161 \pm 24$ \\
\hline & & & Female & $2.85 \pm 1.37$ & $286.6 \pm 98.2$ & $6.6 \pm 4.8$ & $0.57 \pm 0.21$ & $109 \pm 46$ \\
\hline & & 150 & Male & $4.10 \pm 0.49$ & $558.1 \pm 168.6$ & $7.3 \pm 3.7$ & $0.78 \pm 0.23$ & $176 \pm 60$ \\
\hline & & & Female & $6.22 \pm 1.44$ & $882.9 \pm 347.7$ & $7.9 \pm 3.6$ & $0.55 \pm 0.32$ & $127 \pm 34$ \\
\hline & MGAH22 (sixth dose) & 15 & Male & $0.89 \pm 0.11$ & $229.8 \pm 82.1$ & $8.9 \pm 4.3$ & $0.24 \pm 0.12$ & $66 \pm 6$ \\
\hline & & & Female & $0.98 \pm 0.33$ & $209.4 \pm 110.4$ & $8.7 \pm 4.6$ & $0.29 \pm 0.16$ & $90 \pm 51$ \\
\hline & & 50 & Male & $4.90 \pm 5.34$ & $975.5 \pm 747.1$ & $8.8 \pm 3.0$ & $0.22 \pm 0.13$ & $65 \pm 34$ \\
\hline & & & Female & $7.20 \pm 5.70$ & $1,040.4 \pm 657.6$ & $7.3 \pm 4.7$ & $0.20 \pm 0.12$ & $41 \pm 18$ \\
\hline & & 150 & Male & $6.87 \pm 1.64$ & $1,330.3 \pm 456.7$ & $7.3 \pm 3.0$ & $0.36 \pm 0.13$ & $81 \pm 14$ \\
\hline & & & Female & $11.00 \pm 4.89$ & $1,963.5 \pm 1,273.1$ & $8.8 \pm 2.4$ & $0.31 \pm 0.19$ & $73 \pm 36$ \\
\hline
\end{tabular}

Data are presented as mean \pm standard deviation. $A_{U} C_{0-¥}$, area under the curve from zero to infinity; $C_{\text {max }}$ maximal serum concentration; $M G A H 22$, chimeric antiHER2 monoclonal antibody with an optimized Fc domain; RES120, chimeric anti-HER2 monoclonal antibody with wild-type human immunoglobulin G 1 Fc domain; $T_{1 / 2 \beta}$, elimination half-life; $V_{s s}$, volume of distribution at steady state. 
express activating and inhibitory Fc $\gamma$ Rs with substantially enhanced binding to the optimized Fc domain of MGAH22 relative to the WT Fc domain (Figure $2 b$ ). Although the increased binding to the inhibitory CD32B receptor could limit toxicity, it is compensated by the enhanced binding of the activating receptors, which is greater than that observed with human orthologs. When administered by intravenous infusion at a single $50 \mathrm{mg} /$ $\mathrm{kg}$ dose or at 6 weekly doses of 15,50 , or $150 \mathrm{mg} / \mathrm{kg}$, MGAH22 was well tolerated in male and female animals, and there were no clinical signs or treatment-related effects on food consumption, body weights, physical or ophthalmic examinations, blood pressure or heart rate, electrocardiogram, serum troponin I, hematology, serum chemistry, coagulation, or urine analysis parameters at any time during the study. There were no gross or microscopic findings at terminal necropsy attributable to MGAH22 administration and no findings in heart tissue.

Circulating NK cells (measured as $\mathrm{CD}^{-} / \mathrm{CD} 159 \mathrm{a}^{+}$cells by flow cytometry) were decreased, compared with predose levels, by an average of $51 \%$ (range of $40 \%$ to $65 \%$ ) in MGAH22-treated animals compared with 30\% (range of $18 \%$ to $43 \%$ ) in vehicle-treated animals within 1 day of dosing. Declines in NK cells were independent of dose, smaller in magnitude (less than 30\%) after subsequent administrations, and not associated with changes in NK cell cytolytic activity when PBMCs from the treated monkeys were used as effector cells against K562 cells as targets (data not shown).

Low levels of IL-6 (Figure 6a), but not IL-2, IL-4, IL-5, INF- $\gamma$, or TNF- $\alpha$ (data not shown), were transiently induced within 4 hours of infusion of MGAH22, RES120, or vehicle. From baseline levels of not more than $3 \mathrm{pg} / \mathrm{mL}$, mean peak serum IL- 6 levels after the first infusion were 11 to $32 \mathrm{pg} / \mathrm{mL}$ with RES120 or MGAH22 compared with $7 \mathrm{pg} / \mathrm{mL}$ with vehicle. After the sixth infusion in the repeat-dose study, mean peak serum IL-6 levels for all MGAH22 groups (7 to $12 \mathrm{pg}$ / $\mathrm{mL}$ ) were comparable to those in the vehicle group (10 $\mathrm{pg} / \mathrm{mL}$ ). Magnitude and duration of IL- 6 induction by MGAH22 were dose-independent and comparable to those observed with RES120, indicating that cytokine release is not enhanced by the optimized Fc domain. This observation was corroborated by measuring antibody-induced cytokine release from human PBMCs in the presence or absence of immobilized HER2 antigen. The three anti-HER2 mAbs (MGAH22, RES120, and trastuzumab) induced similar levels of IL-6 (Figure 6b), TNF- $\alpha$, and IFN- $\gamma$ (data not shown) in the presence, but not absence, of HER2 antigen.

\section{Discussion}

MGAH22 is a human/mouse chimeric IgG1 anti-HER2 antibody based on mouse clone 4D5, the precursor to trastuzumab. MGAH22 was engineered to maintain the antigen-binding properties of the original antibody while optimizing its interactions with human Fc $\gamma$ Rs, important mediators of antibody function in vivo. The engineered Fc domain of MGAH22 imparts increased affinity for both allelic variants of the low-affinity activating Fc $\gamma \mathrm{R}$, $\mathrm{CD} 16 \mathrm{~A}$, and decreased affinity for the inhibitory Fc $\gamma \mathrm{R}$, CD32B. While maintaining the HER2-binding properties and direct anti-proliferative activity of trastuzumab against sensitive cell lines, these enhanced binding properties confer additional improvements in terms of enhanced anti-tumor activity against HER2-expressing tumor cell lines in vitro; the greatest improvement was observed in ADCC activity against the lower $(1+$ and 2 + ) HER2-expressing cell lines and/or with effector cells isolated from human donors homozygous or heterozygous for the low-binding allele (158F) of CD16A. In vivo, MGAH22 exhibited enhanced anti-tumor activity against a 2+ HER2-expressing cell line in mice genetically deficient for murine CD16 but transgenic for the human CD16A-158F variant.

The Fc $\gamma$ R-binding profile of MGAH22 has many unique aspects. The increased binding affinity to CD16A compares well with that observed with afucosylated trastruzumab [36] or other Fc-engineered mAbs [37-39]. The improvement in MGAH22 binding to the $158 \mathrm{~F}$ allele of human CD16A to levels exceeding those of the WT Fc domain for the $158 \mathrm{~V}$ allele suggests that MGAH22 could provide benefit to patients of any CD16A genotype, but particularly homozygotes or heterozygotes carrying the $158 \mathrm{~F}$ variant, who have poorer outcomes in response to trastuzumab treatment [11]. The increased CD16A binding also resulted in increased effectiveness, particularly against tumor cells expressing low levels of HER2. This suggests that MGAH22 can induce productive synapse formation between tumor and effector cells with fewer antibody-target interactions on the tumor cell surface, presumably by recruiting more Fc receptors on the effector cells per unit of binding or increasing the length of time the receptor is engaged or both. Because the benefit of trastuzumab therapy accrues only to patients with tumors that overexpress HER2 at the $3+$ level or exhibit gene amplification [3,5,40], this finding suggests that MGAH22 may extend such advantages of anti-HER2 therapy to patients whose tumors express low HER2 levels and who are not thought to benefit from trastuzumab treatment.

CD16A is coexpressed with other Fc $\gamma$ Rs on mononuclear phagocytes but is the only Fc $\gamma \mathrm{R}$ expressed by NK cells. These cells are the major contributors to ADCC activity in PBMCs under standard in vitro assay conditions, a notion supported by the observation that enhanced MGAH22-mediated ADCC was also observed with purified NK cells. NK cells have been implicated as 


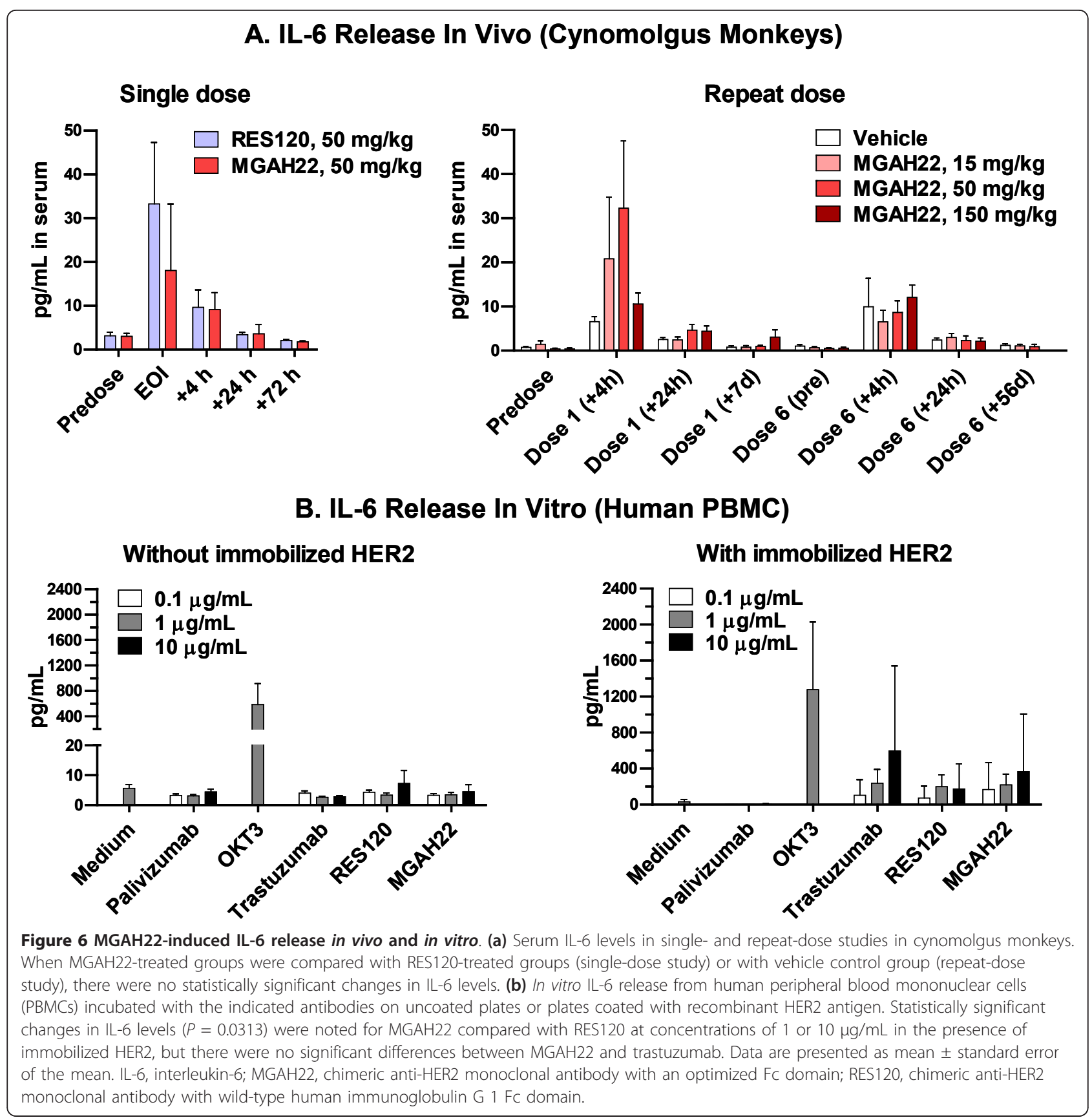

important mediators of the anti-tumor activity of trastuzumab in patients with breast cancer. Trastuzumab treatment is associated with increased numbers of tumor-associated NK cells, and patients with responsive tumors tend to have larger numbers of tumor-infiltrating NK cells $[8,9]$. Patients with higher NK cell numbers exhibit higher levels of trastuzumab-mediated ADCC activity, which has been associated with increased tumor responsiveness $[9,10]$. This finding is consistent with the association between responsiveness to trastuzumab treatment and level of ADCC activity mediated by CD16-expressing cells and CD16A genotype [11].

Another unique feature of the Fc domain of MGAH22 is its decreased binding to the CD32B inhibitory receptor. Fc domains exhibiting decreased fucosylation, by comparison, enhance binding only to CD16A $[39,41]$, and other mutations reported to increase binding to activating receptors also demonstrate increased binding to CD32B but to different extents, depending on the mutations $[37,38]$. When co-engaged with an activating 
Fc $\gamma \mathrm{R}$ on mononuclear phagocyte effectors, CD32B confers an inhibitory signal that counters cell activation. Although no clinical data on an association between reduced $\mathrm{CD} 32 \mathrm{~B}$ binding and response to trastuzumab or other $\mathrm{mAbs}$ are available, non-clinical studies show the importance of Fc-mediated functions exerted by monocytes and macrophages in vivo [42]. Enhanced antitumor responses occur in mice genetically lacking CD32B [7], and enhanced antigen delivery via immune complexes that bind both activating and inhibitory receptors occurs under conditions of $\mathrm{CD} 32 \mathrm{~B}$ blockade [43-45]. These effects may contribute to the ability of immunotherapy to break tolerance in cancer and induce an adaptive immune response. Attempts at modeling the CD32B-dependent component of MGAH22 action in terms of effector cell function have been hampered by the ineffective tumor cytotoxic activity of mononuclear phagocytes in vitro (data not shown) and lack of a suitable animal model. Nonetheless, a decline in binding to $\mathrm{CD} 32 \mathrm{~B}$ is expected to be beneficial by increasing the ratio of activating-to-inhibitory $\mathrm{F} c \gamma \mathrm{R}$ interactions.

In the selection of species for non-human primate toxicology studies, both antigen expression and $\mathrm{Fc} / \mathrm{Fc} \gamma \mathrm{R}$ interactions were considered. Tissue cross-reactivity studies with MGAH22 on human and cynomolgus tissue panels revealed similar antigen distributions, which were comparable to those observed with trastuzumab. Importantly, the binding profile of MGAH22 to cynomolgus monkey Fc $\gamma$ Rs generally supports the use of this species as a relevant toxicology model for the immune effector function of this antibody. Although the engineered Fc domain has increased binding to cynomolgus monkey CD32B, which differs from its decreased binding to human $\mathrm{CD} 32 \mathrm{~B}$ and may limit toxicity in monkeys, it has increased binding to the invariant monkey CD16A and CD32A receptors. Moreover, the binding affinities for these activating Fc $\gamma$ Rs of monkeys exceed those for the high-binding alleles of the human orthologs, a situation that may counteract the potential inhibitory effect of increased binding to monkey $\mathrm{CD} 32 \mathrm{~B}$ and be adequate for evaluating potential toxic effects due to $F c \gamma R$ engagement.

The MGAH22 Fc domain preserves FcRn binding, which favors an extended serum half-life [46]. The terminal half-life of MGAH22 in cynomolgus was 7 to 9 days, approximately $20 \%$ shorter than that of RES120, which contains the WT Fc domain. A similar decline in half-life was observed when afucosylated trastuzumab, exhibiting increased binding to hCD16A, was compared with trastuzumab in hCD16A transgenic mice [36]. Except for a slightly shorter half-life, the pharmacokinetic profile of MGAH22 in cynomolgus monkeys is comparable to that of other anti-HER2 mAbs [34,35]. Importantly, in the single- and repeat-dose toxicology studies, there were no significant antibody-related clinical observations or macro/microscopic findings. The modest dose-independent decrease in circulating NK cells was reminiscent of a similar observation in monkeys treated with an Fc domain-enhanced anti-CD19 $\mathrm{mAb}$ [37]. Given its transient nature, the phenomenon likely results from margination of the NK cells. The Fcengineered MGAH22 mAb was not unusually immunogenic in monkeys, but owing to the lack of predictive value of immunogenicity data in animals [47], the potential incidence of immunogenicity in humans cannot be extrapolated.

Cytokine release could be exacerbated by increased binding to Fc $\gamma$ Rs. MGAH22 induced minimal levels of just IL- 6 in cynomolgus monkeys and IL-6, TNF- $\alpha$, and IFN- $\gamma$ from human PBMCs in vitro that were similar to those induced by RES120 or trastuzumab, suggesting that MGAH22 is unlikely to induce cytokines in patients to levels any higher than those induced by trastuzumab. A potential explanation is that cytokine release may relate more to CD32A than CD16A. CD32A expression by mononuclear phagocytes, but not NK cells, is consistent with the spectrum of observed cytokines, which did not include IL-2, an NK cell-derived cytokine. Binding of MGAH22 to the prevalent CD32A-131H allele is unchanged compared with WT Fc domains, whereas binding to the rarer CD32A-131R allele is decreased, a reflection of the high degree of homology between the extracellular domain and Fc-binding interface of this variant with CD32B (including the arginine at position 131, which is shared by $\mathrm{CD} 32 \mathrm{~B})$. While CD32A polymorphism may contribute to outcomes in patients with trastuzumab-treated metastatic breast cancer, its role is less pronounced than that associated with CD16A polymorphism [11]. Moreover, recent data suggest an association of the $131 \mathrm{H}$ allele of CD32A with the development of trastuzumab-related cardiotoxicity [48]. Thus, the lack of enhanced binding to either of the CD32A alleles may be favorable to the safety profile of MGAH22.

Other novel HER2-directed agents are undergoing clinical development. A trastuzumab-drug conjugate, TDM1, designed to deliver a cytotoxic molecule into HER2-overexpressing cells via receptor-mediated endocytosis [49], has shown a significant advantage in advanced breast cancer, although its benefits appear to be restricted to patients with HER2 $3+$ or gene-amplified tumors [50]. In this context, MGAH22 may have particular utility in patients with low HER2-expressing tumors. An afucosylated version of trastuzumab with increased anti-tumor effector function has also been described [36]. However, MGAH22, by exhibiting diminished binding to the inhibitory Fc $\gamma \mathrm{R}, \mathrm{CD} 32 \mathrm{~B}$, differs from afucosylated trastuzumab, which exhibits a slight increase in binding to this inhibitory receptor. 
MGAH22, by diminishing interactions with this inhibitory $\mathrm{F} c \gamma \mathrm{R}$, would be expected to exhibit additional favorable properties in the presence of mononuclear phagocytic effector cells and potentially further enhanced efficacy against low HER2-expressing tumors or tumors resistant to trastuzumab therapy.

\section{Conclusions}

The favorable safety profile of MGAH22 is reflected by its 'no observed adverse effect level' (NOAEL) in cynomolgus monkeys of $150 \mathrm{mg} / \mathrm{kg}$. The minimal effective human equivalent dose is approximately $0.1 \mathrm{mg} / \mathrm{kg}$, estimated from a minimum effective dose of $1 \mathrm{mg} / \mathrm{kg}$ in xenograft models with human CD16A transgenic mice (10-fold lower than that of the corresponding WT $\mathrm{mAb}$ ). Based on these considerations, a phase 1 doseescalation study with MGAH22 doses ranging from 0.1 to $15 \mathrm{mg} / \mathrm{kg}$ has been initiated in patients with HER2expressing tumors.

\begin{abstract}
Abbreviations
ADA: anti-drug antibody; ADCC: antibody-dependent cell-mediated cytotoxicity; CBA: cytometric bead array; ch4D5-N297Q: chimeric anti-HER2 monoclonal antibody with inactivated FC domain; $\mathrm{EC}_{50}$ : effective concentration for 50\% lysis or 50\% binding; FcyR: Fc-gamma receptor; IFN-ү: interferon-gamma; IgG1: immunoglobulin $G$ 1; IL: interleukin; $K_{D}$ : equilibrium dissociation constant; mAb: monoclonal antibody; MGAH22: chimeric antiHER2 monoclonal antibody with an optimized Fc domain; MGFC0264: human IgG1 FC domain optimized for increased CD16A and decreased CD32B binding; NK: natural killer; PBMC: peripheral blood mononuclear cell; RES120: chimeric anti-HER2 monoclonal antibody with wild-type human immunoglobulin G 1 Fc domain; TNF-a: tumor necrosis factor-alpha; WT: wild-type.
\end{abstract}

\section{Acknowledgements}

We thank Nadine Tuaillon, Sudeepta Aggarwal, and Francine Chen for assistance with xenograft, cell biology, and tissue cross-reactivity studies, respectively; Deryk Loo and Kathryn E Stein for critical review; and Melinda Hanson for expert editorial assistance.

\section{Author details}

${ }^{1}$ MacroGenics, Inc., 9640 Medical Center Drive, Rockville, MD 20850, USA. ${ }^{2} \mathrm{H}$. Lundbeck A/S, Ottiliavej 9, Valby 2500, Denmark.

\section{Authors' contributions}

$S G, W Z, Y Y, H L, S B, L H, V C$, and TZ conducted experiments and helped to analyze data. SJ, PAM, JS and SK helped to conceive and design experiments and analyze data. SJS helped to analyze data. EB and JLN helped to conceive and design experiments, analyze data, and write the paper. All authors read and approved the final manuscript.

\section{Competing interests}

All authors are or have been employed by MacroGenics, Inc., a privately held company, and have received MacroGenics stock options as a condition of employment.

Received: 12 July 2011 Revised: 20 July 2011

Accepted: 30 November 2011 Published: 30 November 2011

\section{References}

1. Slamon DJ, Clark GM, Wong SG, Levin WJ, Ullrich A, McGuire WL: Human breast cancer: correlation of relapse and survival with amplification of the HER-2/neu oncogene. Science 1987, 235:177-182.
2. Cobleigh MA, Vogel CL, Tripathy D, Robert NJ, Scholl S, Fehrenbacher L, Wolter JM, Paton V, Shak S, Lieberman G, Slamon DJ: Multinational study of the efficacy and safety of humanized anti-HER2 monoclonal antibody in women who have HER2-overexpressing metastatic breast cancer that has progressed after chemotherapy for metastatic disease. J Clin Oncol 1999, 17:2639-2648.

3. Slamon DJ, Leyland-Jones B, Shak S, Fuchs H, Paton V, Bajamonde A, Fleming T, Eiermann W, Wolter J, Pegram M, Baselga J, Norton L: Use of chemotherapy plus a monoclonal antibody against HER2 for metastatic breast cancer that overexpresses HER2. N Engl J Med 2001, 344:783-792.

4. Romond EH, Perez EA, Bryant J, Suman VJ, Geyer CE Jr, Davidson NE, TanChiu E, Martino S, Paik S, Kaufman PA, Swain SM, Pisansky TM, Fehrenbacher L, Kutteh LA, Vogel VG, Visscher DW, Yothers G, Jenkins RB, Brown AM, Dakhil SR, Mamounas EP, Lingle WL, Klein PM, Ingle JN, Wolmark N: Trastuzumab plus adjuvant chemotherapy for operable HER2-positive breast cancer. N Engl J Med 2005, 353:1673-1684.

5. Bang YJ, Van CE, Feyereislova A, Chung HC, Shen L, Sawaki A, Lordick F, Ohtsu A, Omuro Y, Satoh T, Aprile G, Kulikov E, Hill J, Lehle M, Ruschoff J, Kang YK: Trastuzumab in combination with chemotherapy versus chemotherapy alone for treatment of HER2-positive advanced gastric or gastro-oesophageal junction cancer (ToGA): a phase 3, open-label, randomised controlled trial. Lancet 2010, 376:687-697.

6. Spector NL, Blackwell $\mathrm{KL}$ : Understanding the mechanisms behind trastuzumab therapy for human epidermal growth factor receptor 2positive breast cancer. J Clin Oncol 2009, 27:5838-5847.

7. Clynes RA, Towers TL, Presta LG, Ravetch JV: Inhibitory Fc receptors modulate in vivo cytoxicity against tumor targets. Nat Med 2000, 6:443-446.

8. Arnould L, Gelly M, Penault-Llorca F, Benoit L, Bonnetain F, Migeon C, Cabaret V, Fermeaux V, Bertheau P, Garnier J, Jeannin JF, Coudert B: Trastuzumab-based treatment of HER2-positive breast cancer: an antibody-dependent cellular cytotoxicity mechanism? Br J Cancer 2006, 94:259-267.

9. Gennari R, Menard S, Fagnoni F, Ponchio L, Scelsi M, Tagliabue E, Castiglioni F, Villani L, Magalotti C, Gibelli N, Oliviero B, Ballardini B, Da PG, Zambelli A, Costa A: Pilot study of the mechanism of action of preoperative trastuzumab in patients with primary operable breast tumors overexpressing HER2. Clin Cancer Res 2004, 10:5650-5655.

10. Varchetta S, Gibelli N, Oliviero B, Nardini E, Gennari R, Gatti G, Silva LS, Villani L, Tagliabue E, Menard S, Costa A, Fagnoni FF: Elements related to heterogeneity of antibody-dependent cell cytotoxicity in patients under trastuzumab therapy for primary operable breast cancer overexpressing Her2. Cancer Res 2007, 67:11991-11999.

11. Musolino A, Naldi N, Bortesi B, Pezzuolo D, Capelletti M, Missale G, Laccabue D, Zerbini A, Camisa R, Bisagni G, Neri TM, Ardizzoni A: Immunoglobulin $\mathrm{G}$ fragment $C$ receptor polymorphisms and clinical efficacy of trastuzumab-based therapy in patients with HER-2/neupositive metastatic breast cancer. J Clin Oncol 2008, 26:1789-1796.

12. Zhang W, Gordon M, Schultheis AM, Yang DY, Nagashima F, Azuma M, Chang HM, Borucka E, Lurje G, Sherrod AE, lqbal S, Groshen S, Lenz HJ: FCGR2A and FCGR3A polymorphisms associated with clinical outcome of epidermal growth factor receptor expressing metastatic colorectal cancer patients treated with single-agent cetuximab. J Clin Oncol 2007, 25:3712-3718.

13. Bibeau F, Lopez-Crapez E, Di FF, Thezenas S, Ychou M, Blanchard F, Lamy A, Penault-Llorca F, Frebourg T, Michel P, Sabourin JC, Boissiere-Michot F: Impact of Fc\{gamma\}RIla-Fc\{gamma\}RIlla polymorphisms and KRAS mutations on the clinical outcome of patients with metastatic colorectal cancer treated with cetuximab plus irinotecan. J Clin Oncol 2009, 27:1122-1129.

14. Pander J, Gelderblom H, Antonini NF, Tol J, van Krieken JH, van der Straaten T, Punt CJ, Guchelaar HJ: Correlation of FCGR3A and EGFR germline polymorphisms with the efficacy of cetuximab in KRAS wildtype metastatic colorectal cancer. Eur J Cancer 2010, 46:1829-1834.

15. Pander J, Heusinkveld M, van der Straaten T, Jordanova ES, Baak-Pablo R, Gelderblom H, Morreau H, van der Burg SH, Guchelaar HJ, van HT: Activation of tumor-promoting type 2 macrophages by EGFR-targeting antibody cetuximab. Clin Cancer Res 2011, 17:5668-5673.

16. Weng WK, Levy R: Two immunoglobulin $G$ fragment $C$ receptor polymorphisms independently predict response to rituximab in patients with follicular lymphoma. J Clin Oncol 2003, 21:3940-3947. 
17. Cartron G, Dacheux L, Salles G, Solal-Celigny P, Bardos P, Colombat P, Watier $\mathrm{H}$ : Therapeutic activity of humanized anti-CD20 monoclonal antibody and polymorphism in IgG Fc receptor FcgammaRIlla gene. Blood 2002, 99:754-758.

18. Canete JD, Suarez B, Hernandez MV, Sanmarti R, Rego I, Celis R, Moll C, Pinto JA, Blanco FJ, Lozano F: Influence of variants of Fc gamma receptors IIA and IIIA on the American College of Rheumatology and European League Against Rheumatism responses to anti-tumour necrosis factor alpha therapy in rheumatoid arthritis. Ann Rheum Dis 2009, 68:1547-1552.

19. Wilson NS, Yang B, Yang A, Loeser S, Marsters S, Lawrence D, Li Y, Pitti R, Totpal K, Yee S, Ross S, Vernes JM, Lu Y, Adams C, Offringa R, Kelley B, Hymowitz S, Daniel D, Meng G, Ashkenazi A: An Fcgamma receptordependent mechanism drives antibody-mediated target-receptor signaling in cancer cells. Cancer Cell 2011, 19:101-113.

20. Sullivan KE, Jawad AF, Piliero LM, Kim N, Luan X, Goldman D, Petri M: Analysis of polymorphisms affecting immune complex handling in systemic lupus erythematosus. Rheumatology (Oxford) 2003, 42:446-452.

21. Kyogoku C, Dijstelbloem HM, Tsuchiya N, Hatta Y, Kato H, Yamaguchi A, Fukazawa T, Jansen MD, Hashimoto H, van De Winkel JG, Kallenberg CG, Tokunaga K: Fcgamma receptor gene polymorphisms in Japanese patients with systemic lupus erythematosus: contribution of FCGR2B to genetic susceptibility. Arthritis Rheum 2002, 46:1242-1254.

22. Nimmerjahn F, Ravetch JV: Fcgamma receptors as regulators of immune responses. Nat Rev Immunol 2008, 8:34-47.

23. Carter P, Presta L, Gorman CM, Ridgway JB, Henner D, Wong WL, Rowland AM, Kotts C, Carver ME, Shepard HM: Humanization of an antip185HER2 antibody for human cancer therapy. Proc Natl Acad Sci USA 1992, 89:4285-4289.

24. Stavenhagen JB, Gorlatov S, Tuaillon N, Rankin CT, Li H, Burke S, Huang L, Johnson S, Koenig S, Bonvini E: Enhancing the potency of therapeutic monoclonal antibodies via Fc optimization. Adv Enzyme Regul 2008, 48:152-164.

25. Stavenhagen JB, Gorlatov S, Tuaillon N, Rankin CT, Li H, Burke S, Huang L, Vijh S, Johnson S, Bonvini E, Koenig S: Fc optimization of therapeutic antibodies enhances their ability to kill tumor cells in vitro and controls tumor expansion in vivo via low-affinity activating Fcgamma receptors. Cancer Res 2007, 67:8882-8890.

26. Code of Federal Regulations, Title 9, Animals and Animal Products. [http://ecfr.gpoaccess.gov/cgi/t/text/text-idx?c=ecfr\&tpl=/ecfrbrowse/Title09/ 9cfr__main_02.tpl].

27. National Research Council, Institute of Laboratory Animal Resources: Guide for the Care and Use of Laboratory Animals Washington DC: National Academy Press; 1996.

28. Tanner M, Kapanen Al, Junttila T, Raheem O, Grenman S, Elo J, Elenius K, Isola J: Characterization of a novel cell line established from a patient with Herceptin-resistant breast cancer. Mol Cancer Ther 2004, 3:1585-1592.

29. Rogers KA, Scinicariello F, Attanasio R: IgG Fc receptor III homologues in nonhuman primate species: genetic characterization and ligand interactions. J Immunol 2006, 177:3848-3856.

30. Nimmerjahn F, Bruhns P, Horiuchi K, Ravetch JV: FcgammaRIV: a novel FcR with distinct IgG subclass specificity. Immunity 2005, 23:41-51.

31. Mancardi DA, lannascoli B, Hoos S, England P, Daeron M, Bruhns P: FcgammaRIV is a mouse IgE receptor that resembles macrophage FcepsilonRI in humans and promotes IgE-induced lung inflammation. J Clin Invest 2008, 118:3738-3750

32. Asada S, Choi Y, Yamada M, Wang SC, Hung MC, Qin J, Uesugi M: External control of Her2 expression and cancer cell growth by targeting a Raslinked coactivator. Proc Natl Acad Sci USA 2002, 99:12747-12752.

33. Perussia B, Ravetch JV: Fc gamma RIII (CD16) on human macrophages is a functional product of the Fc gamma Rlll-2 gene. Eur J Immunol 1991, 21:425-429.

34. Shepard HM, Jin P, Slamon DJ, Pirot Z, Maneval DC: Herceptin. Handb Exp Pharmacol 2008, 181:183-219.

35. Adams CW, Allison DE, Flagella K, Presta L, Clarke J, Dybdal N, McKeever K, Sliwkowski MX: Humanization of a recombinant monoclonal antibody to produce a therapeutic HER dimerization inhibitor, pertuzumab. Cancer Immunol Immunother 2006, 55:717-727.

36. Junttila TT, Parsons K, Olsson C, Lu Y, Xin Y, Theriault J, Crocker L, Pabonan O, Baginski T, Meng G, Totpal K, Kelley RF, Sliwkowski MX:
Superior in vivo efficacy of afucosylated trastuzumab in the treatment of HER2-amplified breast cancer. Cancer Res 2010, 70:4481-4489.

37. Lazar GA, Dang W, Karki S, Vafa O, Peng JS, Hyun L, Chan C, Chung HS, Eivazi A, Yoder SC, Vielmetter J, Carmichael DF, Hayes RJ, Dahiyat Bl: Engineered antibody Fc variants with enhanced effector function. Proc Natl Acad Sci USA 2006, 103:4005-4010.

38. Richards JO, Karki S, Lazar GA, Chen H, Dang W, Desjarlais JR: Optimization of antibody binding to FcgammaRlla enhances macrophage phagocytosis of tumor cells. Mol Cancer Ther 2008, 7:2517-2527.

39. Niwa R, Sakurada M, Kobayashi Y, Uehara A, Matsushima K, Ueda R, Nakamura K, Shitara K: Enhanced natural killer cell binding and activation by low-fucose lgG1 antibody results in potent antibody-dependent cellular cytotoxicity induction at lower antigen density. Clin Cancer Res 2005, 11:2327-2336.

40. Wolff AC, Hammond ME, Schwartz JN, Hagerty KL, Allred DC, Cote RJ, Dowsett M, Fitzgibbons PL, Hanna WM, Langer A, McShane LM, Paik S, Pegram MD, Perez EA, Press MF, Rhodes A, Sturgeon C, Taube SE, Tubbs R, Vance GH, van de Vijver M, Wheeler TM, Hayes DF, American Society of Clinical Oncology/College of American Pathologists: American Society of Clinical Oncology/College of American Pathologists guideline recommendations for human epidermal growth factor receptor 2 testing in breast cancer. Arch Pathol Lab Med 2007, 131:18-43.

41. Shields RL, Lai J, Keck R, O'Connell LY, Hong K, Meng YG, Weikert SHA Presta LG: Lack of fucose on human lgG1 N-linked oligosaccharide improves binding to human Fcgamma RIII and antibody-dependent cellular toxicity. J Biol Chem 2002, 277:26733-26740.

42. Uchida J, Lee Y, Hasegawa M, Liang Y, Bradney A, Oliver JA, Bowen K, Steeber DA, Haas KM, Poe JC, Tedder TF: Mouse CD20 expression and function. Int Immunol 2004, 16:119-129.

43. Boruchov AM, Heller G, Veri MC, Bonvini E, Ravetch JV, Young JW: Activating and inhibitory lgG Fc receptors on human DCs mediate opposing functions. J Clin Invest 2005, 115:2914-2923.

44. Desai DD, Harbers SO, Flores M, Colonna L, Downie MP, Bergtold A, Jung S, Clynes R: Fc gamma receptor IIB on dendritic cells enforces peripheral tolerance by inhibiting effector T cell responses. J Immunol 2007, 178:6217-6226.

45. Dhodapkar KM, Kaufman JL, Ehlers M, Banerjee DK, Bonvini E, Koenig S, Steinman RM, Ravetch JV, Dhodapkar MV: Selective blockade of inhibitory Fcgamma receptor enables human dendritic cell maturation with IL12 p70 production and immunity to antibody-coated tumor cells. Proc Natl Acad Sci USA 2005, 102:2910-2915.

46. Ghetie V, Ward ES: Multiple roles for the major histocompatibility complex class I- related receptor FcRn. Annu Rev Immunol 2000, 18:739-766.

47. Shankar G, Pendley C, Stein KE: A risk-based bioanalytical strategy for the assessment of antibody immune responses against biological drugs. Nat Biotechnol 2007, 25:555-561.

48. Cresti N, Jamieson D, Verrill MW, Pinkilgton M, Boddy AV: Fc\{gamma\}receptor lla polymorphism and cardiotoxicity in patients with breast cancer treated with adjuvant trastuzumab. ASCO Meeting Abstracts 2011, 29:565.

49. Lewis Phillips GD, Li G, Dugger DL, Crocker LM, Parsons KL, Mai E, Blattler WA, Lambert JM, Chari RVJ, Lutz RJ, Wong WL, Jacobson FS, Koeppen H, Schwall RH, Kenkare-Mitra SR, Spencer SD, Sliwkowski MX Targeting HER2-positive breast cancer with trastuzumab-DM1, an antibody-cytotoxic drug conjugate. Cancer Res 2008, 68:9280-9290.

50. Burris HA, Rugo HS, Vukelja SJ, Vogel CL, Borson RA, Limentani S, TanChiu E, Krop IE, Michaelson RA, Girish S, Amler L, Zheng M, Chu YW, Klencke B, O'Shaughnessy JA: Phase II study of the antibody drug conjugate trastuzumab-DM1 for the treatment of human epidermal growth factor receptor 2 (HER2)-positive breast cancer after prior HER2directed therapy. J Clin Oncol 2011, 29:398-405.

\section{doi:10.1186/bcr3069}

Cite this article as: Nordstrom et al: Anti-tumor activity and toxicokinetics analysis of MGAH22, an anti-HER2 monoclonal antibody with enhanced Fcy receptor binding properties. Breast Cancer Research 2011 13:R123. 